\title{
Performanse i kody zła w praktykach genocydalnych - wybrane aspekty i egzemplifikacje
}

\author{
The Performance and Codes of Evil in Genocidal Practices: \\ Selected Aspects and Examples
}

\begin{abstract}
Aвstract: The topic of this article is the use of selected patterns of the imagery of evil within studies of war atrocities and acts of genocide. The characterization of "evil" in this paper is informed by the anthropological perspective, with the imagery of evil juxtaposed against anthropologically (i.e., cultural, human, and reflective) practices of humiliation, violation of taboos, and the location of victims in matrices of impurity and exclusion. In his analysis, the author Martin Pollack considers the contaminated landscape through the lens of the practices of taboo violation, including the prevention of burial and the performance of genocidal rape.
\end{abstract}

KEY WORDS: evil, genocidal practices, contaminated landscape, socio-cultural taboo, genocidal rape

Przedmiotem analiz przedstawionych $\mathrm{w}$ niniejszym artykule są imaginaria społeczne $^{1}$ dotyczące zła oraz strategie odgrywania go w interpretowanych jako performans ${ }^{2}$ praktykach społecznych łączących się ze zbrodniami wojen-

${ }^{1}$ Nawiązując do ujęcia Charlesa Taylora, na potrzeby niniejszej analizy przyjmuję rozumienie imaginarium jako treści umożliwiające podejmowanie praktyk społecznych poprzez nadanie im sensu. Por. Ch. Taylor: Nowoczesne imaginaria społeczne. Przeł. A. Puchejda, K. Szymaniak. Kraków 2010, s. 9-10. Andrzej Leder wskazuje, że imaginarium jest kreowane na bazie symbolicznych treści transmitowanych w różnych środowiskach, w których ludzie uczestniczą (A. Leder: Prześniona rewolucja. Ćwiczenia z logiki historycznej. Warszawa 2014, s. 12).

${ }^{2}$ Bazuję w tym przypadku na Goffmanowskiej metaforze życia społecznego jako teatru oraz rozumieniu performansu społecznego w ujęciu Judith Butler i w koncepcji Keitha Doubta (przedstawiam ją ogólnie w przyp. 5). 
nymi (w tym ludobójstwem). Współczesne imaginarium społeczne dotyczące ludobójstwa związane jest zwłaszcza z Holokaustem, masowymi mordami wymierzonymi w bośniackich muzułmanów podczas wojny domowej w byłej Jugosławii oraz z ludobójstwem w Rwandzie. Analizowane w niniejszym artykule kategorie odnoszę głównie do matryc tabu, dekontekstualizacji oraz rytuału przejścia. Strategie odgrywania zła dotyczą trzech etapów związanych z realizacją praktyk ludobójczych: etapu poprzedzającego ludobójstwo, fazy jego realizacji oraz fazy następującej po nim (fazy postgenocydalnej). W niniejszej analizie uwagę ogniskuję na etapie realizacji strategii ludobójczej oraz na kontekście postgenocydalnym ${ }^{3}$. Nawiązuję do matrycy performansu kulturowego oraz Goffmanowskiej metafory teatru jako kontekstu codziennego życia społecznego. Eksplorując omawiany problem, wykorzystuję metodę analizy treści tekstów o charakterze eseistycznym oraz reportażowym ${ }^{4}$, których przedmiotem są wybrane aspekty rzeczywistości genocydalnej i postgenocydalnej. Zmierzam do udzielenia odpowiedzi na następujące pytania badawcze: 1) W jaki sposób opisywana jest przestrzeń stanowiąca „scenę ludobójstwa”? 2) Jakiego rodzaju praktyki o charakterze tabu kulturowego wykorzystywane są $\mathrm{w}$ praktykach genocydalnych związanych z upokarzaniem ofiar? 3) W jaki sposób opisywana jest rzeczywistość postgenocydalna?

\section{Zło jako kategoria antropologiczna}

Studia nad kategorią zła ulokowane są w różnych dyscyplinach, stanowią przedmiot zainteresowania filozofii, antropologii, psychologii, socjologii,

\footnotetext{
${ }^{3}$ Kwestie dotyczące kontekstu społeczno-kulturowego poprzedzającego ludobójstwo, uwzględniające głównie symboliczny aspekt upowszechniania narracji służących stygmatyzacji przedstawicieli grupy, na którą zbrodnia ma być skierowana, a także racjonalizacji działań poprzez odwołanie do afektów lęku, dumy, poczucia sprawiedliwości, przedstawione są m.in. w następujących pracach: M. Armoudian: In Search of a Genocidal Frame: Preliminary Evidence from the Holocaust and the Rwandan Genocide. "Media, War and Conflict" 2020, Vol. 13, s. 133-152; L.M. Nijakowski: O wyjaśnianiu ludobójstwa i czystek etnicznych za pomoca mitów i emocji. „Kultura i Społeczeństwo" 2006, nr 1-2, s. 153-177; Tenże: Rozkosz zemsty. Warszawa 2013; J. Tokarska-Bakir: Okrzyki pogromowe. Szkice z antropologii historycznej Polski lat 1939-1946. Wołowiec 2012.

${ }^{4}$ Analizie poddano prace o charakterze esejów (M. Canin: Przez ruiny i zgliszcza. Podróż po stu zgładzonych gminach żydowskich $w$ Polsce. Przeł. M. Adamczyk-Garbowska. Warszawa 2019; M. Pollack: Skażone krajobrazy. Przeł. K. Niedenthal. Wołowiec 2014), reportażowym (P.P. Reszka: Płuczki. Poszukiwacze żydowskiego złota. Warszawa 2019; W. Tochman: Jakbyś kamień jadła. Sejny 2002; Tenże: Dzisiaj narysujemy śmierć. Wołowiec 2010) oraz powieści autobiograficzne (M. Jergović: Ojciec. Przeł. M. Petryńska. Wołowiec 2012; M. Zaremba-Bielawski: Dom z dwiema wieżami. Przeł. M. Kalinowski. Kraków 2018).
} 
teologii ${ }^{5}$. Podejmowane $\mathrm{w}$ nich analizy zogniskowane są na różnych kwestiach, takich jak: natura zła (refleksja charakterystyczna dla studiów filozoficznych), kulturowe reakcje na zło (studiowane w ramach badań antropologicznych), funkcjonujące w społeczeństwie struktury normatywne określające normę oraz dewiację negatywną - patologię (rozważania na gruncie socjologii). Skupiając uwagę na kulturowych imaginariach dotyczących zła oraz strategiach odgrywania go, będę odnosiła się głównie do matrycy kulturowej, a w tym kontekście do imaginariów zła, jego symboliki i performansów. Paul Ricoeur, podejmując ulokowaną na pograniczu filozofii i antropologii kulturowej analizę dotyczącą symboliki zła, zestawia je z kategoriami nieczystości i skalania oraz strategiami (kulturowymi obrzędami, performansami) oczyszczenia. Filozof zwraca uwagę, że dążenie do oczyszczenia może przyjmować formę dysfunkcyjnych zachowań kompulsywnych. Pisze, że skalanie jest aktem pogłębiającym nieczystość i postrzega się je jako zdarzenie o charakterze magicznym. Dla faktu wystąpienia skalania (nieczystości, brudu) nie jest zaś konieczna intencja realizującego czyn, ale samo złamanie zakazu ${ }^{6}$. Mary Douglas w antropologicznym studium tabu, czystości i nieczystości, analizując egzemplifikacje praktyk istniejących w różnych kulturach, eksponuje odnoszenie wymienionych kategorii do znaczeń przypisywanych żywności (jadalne vs. budzące wstręt, niejadalne), przestrzeni (przestrzeń świecka vs. sakralna), cielesności i seksualności (stosunki dopuszczalne vs. zakazane) $)^{7}$ Również na część twórczości Zygmunta Freuda można patrzeć $\mathrm{w}$ perspektywie antropologicznej. W pracy Totem i tabu wskazuje on dwa współistniejące znaczenia tabu: jedno - określające, że dany obiekt ma znaczenie sakralne, i drugie - odnoszące się do aspektu afektywnego, określające, że budzi on lęk, jest niebezpieczny, zakazany, nieczysty. Obiekt stanowiący tabu obwarowany jest zakazami moralnymi, a przy tym Freud stwierdza, że „kto przekroczy tabu, ten sam staje się tabu"s, a zatem - nawiązując z kolei do myśli

${ }^{5}$ Keith Doubt w studium, którego przedmiotem jest ludobójstwo, wyodrębnia różne perspektywy/paradygmaty, poprzez odniesienie do których można poddawać analizie to zjawisko. Uwagę ogniskuje w szczególności na perspektywie historycznej, socjologicznej, psychologicznej i filozoficznej. Odnosząc się do paradygmatu socjologicznego, sygnalizuje wyodrębnione przez Talcotta Parsonsa komponenty działania, takie jak: aktor, scena, cel, środki oraz orientacja normatywna (K. Doubt: Understanding Evil: Lessons from Bosnia. New York 2006, s. 5). Doubt szczególną rolę przypisuje orientacji normatywnej oraz działaniu rozumianemu jako wybór określonych celów i środków (z zestawu potencjalnie dostępnych) w danej sytuacji. W takim ujęciu rozumienie praktyk ludobójczych w perspektywie teorii agresji nie jest wystarczające, trzeba wziąć pod uwagę także kulturowy kontekst znaczeń, imaginaria, cele i wartości. Konieczne jest uwzględnienie antropologicznych kategorii rytuału oraz tabu. Doubt zestawia kategorie pogwałcania rytuału kulturowego z łamaniem tabu i transgresją. W zdarzeniach towarzyszących praktykom ludobójczym dopatrzyć się można dekontekstualizacji znaczeń przypisywanych symbolom kulturowym.

${ }^{6}$ Zob. P. Ricoeur: Symbolika zła. Przeł. S. Cichowicz, M. Ochab. Warszawa 2015, s. 33-35.

7 Por. M. Douglas: Czystość i zmaza. Przeł. M. Bucholc. Warszawa 2013.

8 Z. Freud: Totem i tabu. Przeł. M. Poręba, R. Reszke. Warszawa 1997, s. 35. 
Ervinga Goffmana - nosi stygmat dewiacyjny. Kulturowo rozumiana zmaza jest pochodną brudu traktowanego jako konsekwencja braku szacunku dla konwencji kulturowej i zaniedbanie jej'. William C. Olsen i Thomas J. Csordas wskazują na kategorię zła analizowanego w kontekście paradygmatu antropologicznego. $\mathrm{W}$ takim ujęciu jest ono postrzegane jako fakt poddający się analizie empirycznej, wyrażający się w działaniu, myśli oraz specyficznych relacjach społecznych tego typu przemocy, okrucieństwa, nadużyć, zaniedbań, przestępczości, a na poziomie afektywnym - nienawiści. Cechą zdarzeń o charakterze zła są ich jednoznacznie destruktywne konsekwencje ${ }^{10}$. Z kolei Jerzy S. Wasilewski zestawia tabu z pierwotnymi emocjami, takimi jak: strach, groza, przerażenie. Nawiązując do prac René Girarda, Wasilewski podtrzymuje tezę, że antropologiczną podstawą tabu jest lęk przed przemocą ${ }^{11}$.

Można założyć, że społeczne i kulturowe postrzeganie przestrzeni, gdzie odbyły się praktyki ludobójcze, wpisuje się w paradygmat studiów nad tabu. Jest to przestrzeń budząca ambiwalentne emocje grozy, przerażenia, współczucia i winy, skalana skrajnymi formami przemocy, dehumanizacji, pozbawiania godności, upokarzania, a także tabuizowana ze względu na - w wielu przypadkach - cały czas znajdujące się w jej obrębie szczątki ludzkie.

\section{Skażony krajobraz - przestrzeń postludobójcza}

Przestrzeń, w której rozgrywają się zdarzenia społeczne, stanowi - nawiązując do teorii Ervinga Goffmana - ich scenę oraz kulisy, poszczególne jej komponenty są przeżywane, odczuwane, konstruowane, nadawane są im symboliczne znaczenia. Poprzez wykorzystanie Goffmanowskiego paradygmatu analizować można przestrzeń stanowiącą kontekst ludobójstwa i postludobójczą. Jej charakterystyki uwzględniają naturalną specyfikę terenu umożliwiającego ukrycie zbrodni, modyfikowanie go przez agresorów, opisy żywiołowo występujących komponentów (na przykład dotyczących zapachu), a także - w odniesieniu do kontekstu postludobójczego - nadawanie przestrzeni znaczeń przez ludność zamieszkującą tereny przyległe.

Martin Pollack miejsca, w których dochodziło do masowych mordów, „dokonywan[ych] w ukryciu, z dala od ludzi, często w ścisłej tajemnicy. Gdzie sprawcy po masakrze dokonywali wszelkich starań, by zatrzeć ślady" ${ }^{\prime 2}$, nazywa

9 Por. tamże, s. 51.

10 Por. W.C. Olsen, Th.J. Csordas: Introduction. In: Engaging Evil: A Moral Anthropology. Eds. W.C. Olsen, Th.J. Csordas. New York-Oxford 2019, s. 1-2.

11 Por. J.S. Wasilewski: Tabu. Warszawa 2010, s. 263-264.

12 M. Pollack: Skażone krajobrazy..., s. 20. 
skażonymi krajobrazami. Ich komponenty to doły, do których wrzucano zamordowanych, a które po zasypaniu były „zazieleniane, starannie obsadzane krzewami i drzewami”"13 gatunków, które „szybko rosną, aby zatrzeć przypadkowe ślady", a przy tym są charakterystyczne dla danego ekosystemu, takie jak między innymi łubin (w Treblince i Bełżcu) lub sosna ${ }^{14}$.

Pollack pisze, że przestrzenie stanowione przez skażone krajobrazy w rozumieniu społeczno-kulturowym są tabu, naznaczone stygmatem historii, nie buduje się na nich infrastruktury niegodnej (ludycznej, rekreacyjnej). Autor eseju stawia jednak pytanie - „Jak to jest mieszkać obok, albo, w niektórych przypadkach, dosłownie, na grobach?"15.

W literaturze można odnaleźć liczne egzemplifikacje opisów dotyczących życia obok miejsc, w których dochodziło do zbrodni ludobójstwa. Ze względu na przedmiot niniejszej analizy nie dokonuję próby przedstawienia ich typologii, a koncentruję się jedynie na tych przykładach, które wpisują się w matrycę opisu aktów łamania tabu społeczno-kulturowego. Do kontekstu tego nawiązuje Paweł Reszka ${ }^{16}$. Przedstawia on zamieszkiwanie obok skażonego krajobrazu jako fakt ulokowany w ambiwalencji codziennych praktyk (własnych lub dokonywanych przez sąsiadów, ale o których to praktykach wszyscy wiedzą) łamania tabu przy jednoczesnym wykorzystywaniu strategii neutralizacji służących usprawiedliwieniu czynu złego lub też, nawiązując do systemu wiedzy religijnej grzesznego. Będący kontekstem przestrzennym dziejów postludobójczych teren byłego obozu zagłady w Bełżcu, nazywany Kozielskiem, opisywany jest jako teren piaszczysty. Piasek obsuwał się podczas kopania w nim głębokich dołów, sięgających do kości nazywanych w dialekcie poszukujących żydowskiego złota żużlem lub rąbanką, w sytuacji gdy zwłoki nie były jeszcze zupełnie rozłożone ${ }^{17}$. W opinii mieszkańców okolic przylegających do obozu zagłady ziemia należąca do jego terenu „była nasączona złotem” ${ }^{18}$. Odkopywanie, wybieranie, a następnie sprzedawanie znalezionych przedmiotów usprawiedliwiano za pomocą technik racjonalizacji, zwłaszcza pomniejszania szkody: „To kopanie, to i tak nie pomogło ani nie zaszkodziło umarłemu. Nic złego nikt nie robił. To, com znalazł, to by i tak przepadło” 19 , i odwołania do racji wyższych: „Tu bieda była” ${ }^{20}$ (a zatem, jak można się domyślać, ubóstwo w przekonaniu sprawców tłumaczy rabowanie zwłok), oraz dewaluowania ofiar: „Tu Żydów ludzie raczej nie lubieli. Lichwiarze

\footnotetext{
13 Tamże.

14 Por. tamże, s. 21.

15 Tamże, s. 27.

16 P.P. Reszka: Płuczki...

17 Por. tamże, s. 14-15.

18 Tamże, s. 39.

19 Tamże, s. 18.

20 Tamże, s. 45.
} 
i oszuści trochę"21. Podczas przeszukiwania żużlu znajdowano przedmioty, którym przypisywano status kosztowności, rzeczy cennych - pierścionki, obrączki, zegarki, ale także koronki stomatologiczne. Przestrzeń Kozielska traktowana była w sposób pragmatyczny jako teren pozyskiwania zasobów. Warto dodać, że zwyczajowo nie poszukiwano złota w niedzielę, którą ",trzeba było uszanować"22. Miejsce kopania dołów wyposażone było w stół służący przeszukiwaniu wydobytej mieszaniny ziemi i szczątków ludzkich. Czynności towarzyszył dyskomfort związany $\mathrm{z}$ odorem rozkładających się zwłok, dlatego uczestniczący w tym procederze mieli specjalnie przeznaczoną do tego odzież, która po powrocie do domu była zostawiana poza częścią mieszkalną ${ }^{23}$. Incydentalnie tylko dostrzega się ulokowane $\mathrm{w}$ matrycy świadomości łamania tabu społeczno-kulturowego wskazanie na pozyskiwane poprzez rabowanie zwłok przedmioty jako na skażone, krwawe i „niedorobne” („Na krwi przelanej się nie dorobisz” ${ }^{24}$ ).

Posługiwanie się zastępczymi terminami (takimi jak we wcześniej przedstawionym przykładzie: żużel, rąbanka, stół) nie jest wyjątkowe. Martin Pollack, nawiązując do pracy Hermanna Lönsa, pisze o tym, jak dolnosaksońscy chłopi w czasie wojny trzydziestoletniej traktowanych jako półludzi Cyganów bronowali, co oznaczało "grzebanie [...] gdzie popadnie, na bagnach albo w dzikim gąszczu, bez kamienia czy krzyża”25. Z kolei sam termin „bronowanie” oznaczał rolniczą technikę radzenia sobie z dziko porastającymi pola, uciążliwymi chwastami - polegało to na przewróceniu ziemi i przeoraniu jej za pomocą pługa.

Obszerne opisy krajobrazu postludobójczego zawiera praca Mordechaja Canina. Opisując teren pozostały po obozie zagłady w Sobiborze, autor zwraca uwagę na pustkę terenu opuszczonego przez ludzi. Nie jest to przestrzeń obwarowana tabu i związaną z nim ambiwalencją grozy oraz szacunku, ale nacechowana chaosem, zaniedbana, zaśmiecona rozbitymi cegłami, szmatami, kawałkami papieru. Canin wskazuje na nietypowy kolor ziemi wymieszanej $\mathrm{z}$ popiołem pochodzącym ze spalonych ludzkich ciał $^{26}$. Jednocześnie przez teren byłego obozu zagłady - jak pisze autor eseju - przeszła już gorączka złota, podczas której „każdy wziął, co chciał, rozkopał, przeorał i zostawił na pastwę losu"27. Mordechaj Canin podejmuje - dziś powiedzielibyśmy: postantropocentryczny - trop, opisując włączenie prochów pomordowanych w system świata przyrody - w substancję rzek i lasu, którego „zieleń będzie soczystsza, a krzewy delikatniejsze"28. Przeciwstawia go jednak komponentowi kulturowemu, w któ-

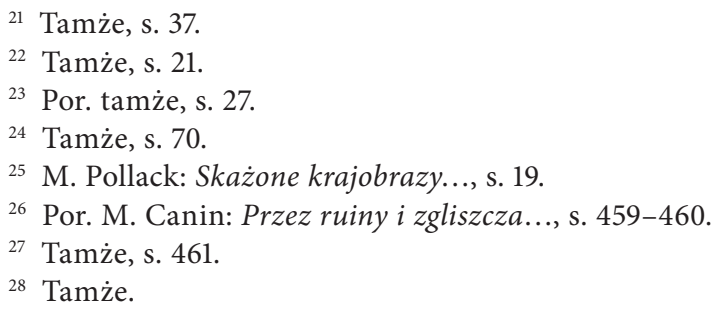


rym zbrodnia ludobójstwa została wyciszona i wyparta, „nikomu nie przyszło do głowy postawić w tym miejscu macewę, zostawić jakiś znak - bo to jest Sobibór, bo tu zginęli tylko Żydzi"29.

Do motywu ziemi, w której znajdują się niegodnie złożone, niepochowane przez bliskich, a czasem $\mathrm{w}$ ogóle niepogrzebane szczątki pomordowanych, nawiązuje także Wojciech Tochman w opisie postludobójczej Rwandy. Kulturowemu rytuałowi pochówku badacz przeciwstawia naturalne wchłanianie ciał przez ziemię w wyniku aktywności bakterii, robactwa, większych zwierząt i deszczy. $\mathrm{W}$ wymiarze imaginarium jednak, jak pisze autor reportażu, ziemia mieszkańców „niepokoi, dręczy. Ruszysz motyką, a ona cię oskarża. Ziemia sumienie. Ziemia - mroczne archiwum, baza danych, twardy dysk. Ziemia prokurator" ${ }^{30}$. Można uznać, że w ujęciu Canina oraz Tochmana dostrzegalny jest postantropocentryczny obraz rzeczywistości postgenocydalnej, w którym z wyrządzonym przez sprawców złem i doznanym przez ofiary cierpieniem współwystępuje szkoda wyrządzona bytom nie-ludzkim: ziemi, krajobrazowi, roślinności ${ }^{31}$. W świecie postgenocydalnym skażona natura staje się źródłem codziennych komunikatów o ludobójczej przeszłości.

Przyjmując perspektywę skażonego krajobrazu, można przytoczyć także kontekst umiejscowienia praktyk ludobójczych w okolicy rzeki Driny na pograniczu serbsko-bośniackim. Drina ma w tym rejonie - zarówno dla Boszniaków, jak i Serbów - wyjątkowy status tożsamościowy, symboliczny i kulturowy. Ivo Andrić jugosłowiański laureat Literackiej Nagrody Nobla $-\mathrm{z}$ perspektywy obserwatora ulokowanego na znajdującym się na Drinie historycznym moście przedstawił losy wielokulturowej społeczności pogranicza bośniacko-serbskiego ${ }^{32}$. Rzeka ta bierze swój początek pomiędzy miejscowościami Hum i Vučevo na pograniczu Bośni i Hercegowiny oraz Czarnogóry, powstaje z połączenia rzek Piva oraz Tara. Przepływa przez obszar wschodniej Bośni do miejscowości Brod, gdzie skręca nieco w kierunku południowym ku miejscowościom Foča, Goražde, Višegrad, następnie kieruje się na północ w kierunku Luki, a później znowu na południe, płynąc aż do miejscowości Bosanska Rača i Crna Bara wzdłuż granicy Federacji Bośni i Hercegowiny oraz Serbii ${ }^{33}$. Tytułowy, znajdujący się w Višegradzie ottomański most oraz płynąca pod nim rzeka opisywane są w powieści Andricia z detalami, podobnie jak rozgrywające się $\mathrm{w}$ ich otoczeniu zdarzenia społeczno-polityczne. W poprzedzającej wojnę nacjonalistycznej propagandzie serbskiej Drina nazywana

29 Tamże.

30 W. Tochman: Dzisiaj narysujemy śmierć..., s. 77.

31 Odniesienie do ujęcia postantropocentrycznego przedstawiam w nawiązaniu do koncepcji Rosi Braidotti zawartej w jej książce Po człowieku (przeł. J. Bednarek, A. Kowalczyk. Warszawa 2014).

32 I. Andrić: Most na Drinie. Przeł. H. Kalita. Warszawa 1985.

33 https://www.google.pl/maps/place/Drina+River/@44.2072866,19.0789061,10z/data=!4m5!3 m4!1s0x4759a07b36f559c9:0x5ca5c9d03b0abc37!8m2!3d44.2072866!4d19,3590575. 
była „kręgosłupem narodowego organizmu”34. Hikmet Karčić pisze, że z punktu widzenia Boszniaków Drina ma kulturowo niemal sakralny charakter, a jednocześnie z opowieściami o niej łączone są narracje dotyczące cierpienia narodu. W czerwcu 1992 roku działania ludobójcze nadały jej nowe znaczenie - według badacza w tym czasie do rzeki wrzucano tak wiele zwłok osób zamordowanych, że dyrektor elektrowni wodnej $\mathrm{w}$ rozmowie telefonicznej prosił o spowolnienie tempa tego procederu, ponieważ ciała zapchały zaporę ${ }^{35}$. Zwłoki zamordowanych wrzucane były także do rzeki Sawy w miejscowości Brčko w północno-wschodniej Bośni ${ }^{36}$. Jest to kolejna egzemplifikacja skażonego krajobrazu stanowiącego kontekst analizowanych aktów ludobójczych i postludobójczych.

\section{Pogwałcenie tabu kulturowego jako komponent scenariusza genocydalnego}

Można przyjąć, że scenariusze genocydalne opierają się na trzech zasadniczych komponentach: pierwszym $\mathrm{z}$ nich jest upowszechnienie narracji usprawiedliwiających podjęcie aktów skrajnej przemocy, neutralizujących poczucie odpowiedzialności i winy za czynne lub bierne uczestnictwo w nich; drugi to wdrożenie technik umożliwiających eksterminację; trzecim komponentem zaś są bazujące na zmiennych antropologicznych strategie upokarzania ofiar oraz dezorganizowania społeczności (poprzez wyłączanie ich członków, osłabianie więzi społecznych, stymulowanie występowania afektu wstydu i poczucia winy). $\mathrm{W}$ niniejszej analizie zogniskuję uwagę na trzecim z wymienionych elementów, jako egzemplifikację traktując łamanie tabu towarzyszącego śmierci oraz łamanie tabu seksualnego. Komponentem łączącym owe dwie kategorie praktyk jest eksponowany w perspektywie antropologicznej fakt, że w znacznym stopniu służą one osłabieniu struktur społecznych (rodzin, wspólnot) grupy etnicznej, na którą ukierunkowana jest czystka bądź działania ludobójcze.

Jedną z uznanych $w$ antropologii wczesnych praktyk kulturowych jest grzebanie zwłok osób zmarłych ${ }^{37}$. To praktyka mająca oprócz znaczenia społeczno-

${ }^{34}$ E. Becirević: Genocide on the Drina River. New Haven-London 2014, s. 82.

${ }^{35}$ Por. H. Karčić: Uncovering the Truth: The Lake Perućac Exhumations in Eastern Bosnia. "Journal of Muslim Minority Affairs" 2017, Vol. 37, no 1, s. 115.

${ }^{36}$ Comission on Human Rights, Forty-ninth Session, Agenda Item 27, Report on the Situation of Human Rights in the Territory of the Former Yugoslavia Submitted by Mr. Tadeusz Mazowiecki. Dostępne w Internecie: https://documents-dds-ny.un.org/doc/UNDOC/GEN/G93/ 106/07/pdf/G9310607.pdf?OpenElement [data dostępu: 16.07.2020].

${ }^{37}$ Ewa Nowicka wskazuje na pojawienie się w filogenezie homo sapiens praktyk łączących się z pochówkiem i ze zdobieniem związanych z nim miejsc jako ważny antropologiczny wskaźnik 
-kulturowego również istotne znaczenie psychologiczne. W studiach z obszaru terapii osób znajdujących się w sytuacji uchodźczej jako jeden $\mathrm{z}$ istotnych faktów ograniczających możliwość przepracowania żałoby wymienia się brak możliwości pochowania bliskich zmarłych (na przykład w sytuacji, gdy ich zwłoki znajdują się w miejscu niemożliwym do zlokalizowania lub z jakiegoś powodu niedostępnym $)^{38}$. Antoni Kępiński stwierdza, że jedną ze strategii dehumanizacji w warunkach obozu koncentracyjnego było upodlenie śmierci, celowe łamanie kulturowego tabu nakazującego szacunek dla śmierci oraz osób zmarłych, a w efekcie zaprzeczenie człowieczeństwu więźnia obozu ${ }^{39}$. Martin Pollack pisze z kolei, że "podczas pogrzebu podkreśla się niepowtarzalną tożsamość zmarłego", a odmowa godnego pochówku jest „wyrazem głębokiej pogardy dla ofiar, które upokarza się jeszcze po śmierci [...], chce się w ten sposób po wsze czasy odmówić im przynależności do rodzaju ludzkiego. Nie traktuje się ich jak istoty ludzkie, lecz jak bezwartościowych podludzi, którzy nie zasłużyli na lepszy los"30.

Praktyki upokarzania ulokowane $\mathrm{w}$ matrycy łamania tabu związanego z nienaruszaniem ciał osób zmarłych towarzyszą procederom ludobójczym. Keith Doubt w analizie aktów poniżania podczas wojny domowej na Bałkanach wymienia uniemożliwianie pochówku zabitych. Członkowie rodzin byli wtedy zmuszani do pozostawiania zwłok swoich bliskich $\mathrm{w}$ miejscach niegodnych (na ulicy, na polu itp.). Pochowanie zmarłych było uniemożliwiane między innymi poprzez umieszczenie granatów $\mathrm{w}$ miejscu znajdowania się zwłok, otaczanie przestrzeni, w której leżały ciała zamordowanych, minami, zabijanie przez snajperów osób uczestniczących w ceremoniach pochówku ${ }^{41}$.

W bazującym na funkcjonalizmie ujęciu antropologicznym rytuały (w tym rytuał pochówku) pełnią szereg funkcji zarówno służących umocnieniu spójności społecznej poprzez wspólnotę uczestnictwa oraz zwerbalizowaniu roli, jaką zmarły odgrywał we wspólnocie lub stowarzyszeniu, jak i służących przywróceniu równowagi emocjonalnej bliskim zmarłego poprzez udzielenie im wsparcia, umożliwienie ekspresji emocji, okazanie współczucia. Uniemożliwienie pochówku jest aktem blokującym możliwość osiągnięcia celów założonych w wymienionych funkcjach, a w efekcie stwarzającym ryzyko osłabienia kondycji indywidualnej poszczególnych osób, ale także kondycji kolektywnej wspólnoty. Kreuje ryzyko wystąpienia poczucia winy i wiktymizacji w sytuacji, gdy rodzina ma wątpliwości, czy podjęła wszystkie potencjalnie dostępne działania, aby po-

\footnotetext{
pozwalający wnioskować o wczesnych praktykach ceremonialnych oraz potencjalnie występujących wyobrażeniach o losach człowieka po śmierci; por. E. Nowicka: Świat człowieka - świat kultury. Warszawa 1991, s. 234-235.

${ }_{38}$ Zob. np. D. Blackwell: Counselling and Psychotherapy with Refugees. London 2005, s. 44-45.

${ }^{39}$ Por. A. Kępiński: Rytm życia. Kraków 1978, s. 17.

${ }^{40}$ M. Pollack: Skażone krajobrazy..., s. 27-28.

${ }^{41}$ Por. K. Doubt: Understanding Evil..., s. 16-18.
} 
chować jej członka ${ }^{42}$. Doubt wskazuje, że praktyki ludobójcze są w konsekwencji wzmacniane destrukcją wspólnoty - socjobójstwem ${ }^{43}$.

Drugim analizowanym typem praktyk towarzyszących czystkom etnicznym i ludobójstwom, mającym na celu upokarzanie grup społecznych i osłabianie ich spójności, jest przemoc seksualna. Ricoeur podkreśla, że w systemie aktów określanych jako kalające szczególny status przypisywany jest łamaniu zakazów dotyczących sfery seksualnej, a przede wszystkim zakazu kazirodztwa ${ }^{44}$. Zbrodniom wojennym (w tym aktom ludobójczym) niejednokrotnie towarzyszą praktyki upokarzania ofiar poprzez wykorzystanie środków związanych z łamaniem tabu seksualnego. Najczęściej opisywane są w takim kontekście gwałty wojenne oraz gwałty genocydalne, ale także praktyki skrajnego upokarzania polegające na zmuszaniu do podejmowania kazirodczych aktów seksualnych. Kwestię tę przedstawia w analizie antropologicznej dotyczącej aktów genocydalnych podczas wojny domowej w byłej Jugosławii Keith Doubt, zaś w reportażu prezentującym ludobójstwo w Rwandzie - Wojciech Tochman ${ }^{45}$.

Gwałty stanowiły typowy komponent rzeczywistości ludobójczej zarówno podczas wojny domowej na terenie byłej Jugosławii, jak i w czasie wojny domowej $\mathrm{w}$ Rwandzie. Podczas wojny $\mathrm{w}$ byłej Jugosławii gwałty popełniano $\mathrm{w}$ przypadkowych miejscach (głównie $\mathrm{w}$ domach ofiar), ale kobiety były też umieszczane w intencjonalnie tworzonych obozach (między innymi w Omarskiej ${ }^{46}$ ), gdzie przemocy seksualnej dokonywano na nich tak długo, aż zmarły lub zaszły w ciążę, a wtedy z kolei były przetrzymywane w obozie do momentu, gdy nie było już możliwości przeprowadzenia aborcji ${ }^{47}$. Tatjana Takševa pisze, że podczas konfliktu na Bałkanach kobiety były gwałcone i celowo zapładniane, w efekcie czego w ciążę zaszło (w zależności od źródła danych) między 25 tys. a 40 tys. muzułmańskich Boszniaczek. Praktykom takim towarzyszyła poniżająca, ideologiczna narracja, która miała zachęcać do wykluczenia kobiety

42 Por. tamże, s. 20-21.

43 Por. tamże, s. 22.

44 Por. P. Ricoeur: Symbolika zła..., s. 27.

45 W. Tochman: Dzisiaj narysujemy śmierć...

46 Zob. np. E. Vulliamy: Wojna umarła, niech żyje wojna. Bośniackie rozrachunki. Przeł. J. Ochab. Wołowiec 2016. Ed Vulliamy w przywołanym reportażu zwraca uwagę, że jeśli weźmie się pod uwagę kryterium ilościowe, przemoc seksualna podczas wojny odbywa się w interakcji między agresorem - mężczyzną, i ofiarą - kobietą, występują jednak także takie formy upokarzania o charakterze seksualnym, jak gwałty na mężczyznach (por. tamże, s. 86-87). Jest to temat poddawany bardzo rzadkim eksploracjom, silnie wyciszany w zmaskulinizowanej kulturze, częściej pojawiający się w publicystyce, reportażu niż w opracowaniach naukowych (por. np. M.G. Djurdjevic: Wartime Rapes of Men Remains Taboo in Bosnia. „Balkan Transitional Justice”, 18.05.2017. Dostępne w Internecie: https:/balkaninsight.com/2017/05/18/male-victims-ofwar-related-sexual-abuse-shunned-in-bosnia-05-18-2017-1/ [data dostępu: 20.06.2020]).

47 Por. Ch.W. Mullins: "We Are Going to Rape You and Taste Tutsi Women". Rape During the 1994 Rwanda Genocide. "British Journal of Criminology” 2009, Vol. 49, s. 719. 
i dziecka z patriarchalnej społeczności - urodzone dziecko miało zostać wychowane na serbskiego nacjonalistę, który zwróci się przeciwko własnej matce. Antropologicznym celem tego typu praktyki ludobójczej było usunięcie kobiety poza kulturową granicę własnej grupy etnicznej, a w konskewencji osłabienie i destabilizacja społeczności, a ponadto w kulturze patrylinearnej (gdzie dziecko należy do linii rodowej ojca) liczebne wzmocnienie grupy etnicznej reprezentowanej przez agresora ${ }^{48}$. Jest to interpretacja podobna do tezy Olsena i Csordasa, którzy pokazują, że w perspektywie antropologicznej akty zła o charakterze strukturalnym mogą być ukierunkowane na destrukcję ontologicznego bezpieczeństwa bazującego na przynależności jednostki do świata ${ }^{49}$. W efekcie zgwałcona kobieta, która urodziła dziecko wroga, zostaje w kulturze patrylinearnej ulokowana poza obszarem społecznych zobowiązań ${ }^{50}$.

Jonathan Gottschall wskazuje na cztery teorie odnoszące się do etiologii przemocy seksualnej towarzyszącej konfliktom zbrojnym, zogniskowane odpowiednio na czynnikach: społecznych, kulturowych oraz biologicznych. Są to teorie: feministyczna, patologii kulturowej (cultural pathology theory), gwałtu strategicznego (the strategic rape theory) i biospołeczna. Zgodnie $\mathrm{z}$ teorią feministyczną kulturowe znaczenie gwałtów wojennych związane jest $\mathrm{z}$ symboliczną ekspresją dominacji mężczyzn nad kobietami; gwałty te są wyrazem mizoginii kulturowej w społeczeństwie patriarchalnym. Stanowią przejaw solidarności mężczyzn, którzy funkcjonują w roli wojowników (niezależnie, po której stronie konfliktu się znajdują), a w takiej sytuacji rolą obcą, wrogą staje się kobiecość. Z kolei teoria patologii kulturowej nawiązuje do założeń psychoanalizy. Zakłada ona, że w historii społeczeństw umiejscowione są zdarzenia, których sposób interpretacji i przeżywania usprawiedliwia gwałty wojenne. Są to na przykład: sadomasochistyczne matryce ulokowane w sposobie wychowania dzieci, militaryzacja kultury, której towarzyszy dewaluacja kobiecości i przyzwolenie na przemoc wobec kobiet, popularność pornografii $\mathrm{w}$ okresie poprzedzającym wybuch wojny ${ }^{51}$. Teoria gwałtu strategicz-

${ }^{48}$ Por. T. Takševa: Genocidal Rape, Enforced Impregnation, and the Discourse of Serbian National Identity. "Comparative Literature and Culture" 2015, Vol. 17, Issue 3, s. 2-3.

${ }^{49}$ Por. W.C. Olsen, Th.J. Csordas: Introduction..., s. 22.

${ }^{50}$ Analogiczny mechanizm rozpoznawany jest w studiach (zarówno naukowych, jak i w reportażu) dotyczących wojny domowej w Rwandzie. Wojciech Tochman przytacza fragment testimonium kobiety należącej do plemienia Tutsi, która w wyniku gwałtu zaszła w ciążę. W zamieszczonym w reportażu świadectwie tak opisuje ona swój stosunek do syna: „Nie kocham tego chłopaka. Patrzę na niego i widzę tamtych [...] Jak zadra jakaś. Hutu w moim domu”. Następnie zaś opowiada o swoim naznaczonym stygmatem i poczuciem winy statusie w społeczności: „Wszyscy mi zarzucają jego istnienie, zarzucają, że go urodziłam. Wszyscy widzą ten podpis morderców. Nigdzie przez to nie chodzę. Nikt mnie nie zaprasza na chrzciny. Ani na wesele. Moja matka poszła teraz w pole [...]. Jej dzieci zostały przez nich zabite [...] Ona mu powtarza [...] Twój ojciec zabił moje dzieci” (W. Tochman: Dzisiaj narysujemy śmierć..., s. 40-41).

${ }^{51}$ Por. J. Gottschall: Explaining Wartime Rape. "The Journal of Sex Research" 2004, Vol. 41, no 2, s. 129. Tochman jako jeden z komponentów spektrum symbolicznego wykreowanego 
nego zakłada, że gwałty wojenne są środkiem terroru, mają na celu osłabienie zdolności ludności cywilnej do stawiania oporu, są także wykorzystywane jako strategia demoralizacji oraz upokarzania mężczyzn, których wskazuje się jako niezdolnych do zapewnienia bezpieczeństwa grupie. Wtórnie przemoc seksualna służy - w przytoczonym rozumieniu - osłabieniu spójności kulturowej, struktur rodzinnych, jest również traktowana jako środek zmniejszania potencjału reprodukcyjnego grupy. $\mathrm{Z}$ tego względu w kontekście teorii gwałtu strategicznego gwałty wojenne są też określane jako gwałty ludobójcze ${ }^{52}$. Riki van Boeschoten twierdzi, że osoby zgwałcone podczas wojny stanowią grupę ofiar najbardziej wyciszanych. Gwałt nie pozostawia stałych konsekwencji fizycznych na ciele ofiary, jest $w$ związku z tym podczas wojny niewidoczny zarówno fizycznie, jak i politycznie ${ }^{53}$. Cindy S. Snyder, Wesley J. Gabbard, J. Dean May i Nihada Zulcic eksponują w swojej analizie przedmiotowego zjawiska perspektywę genderową, wyjaśniającą fakt wyciszania gwałtów wojennych androcentryzmem oraz mizoginią jako skryptami poznawczymi ulokowanymi w kulturze. Gwałt w kontekście takiej interpretacji traktuje się jako pochodną kulturowych kodów, według których kobieta jest podporządkowana mężczyźnie. Dodatkowo kontekst wojny lokuje kobiety i mężczyzn w przestrzeni dwóch antagonistycznych światów. Mężczyźni, walcząc nawet przeciwko sobie, jednocześnie dysponują wspólną tożsamością militarną. W takiej sytuacji rola zewnętrzna, odmienna przypisana jest kobietom niewalczącym, które w konsekwencji uzyskują status wroga. Efektem stygmatyzacji jest brak możliwości ustalenia liczby kobiet, które zostały zgwałcone podczas wojny w Bośni - szacuje się, że było to 25-50 tys. Zbiorowe gwałty, dokonywane w przestrzeni publicznej, przyjmowały charakter spektakli, były traktowane jako narzędzie terroru, upokorzenia i stygmatyzowania kobiet, ale miały także wymiar kulturowy, antropologiczny oraz stanowiły instrument upokorzenia bośniackich muzułmanów, których kultura charakteryzuje się patrylinearyzmem i patrylokalnością. Kobieta należy do linii rodowej męża, a jej upokorzenie jest upokorzeniem rodu mężczyzny, w dalszej kolejności zaś grupy etnicznej i kultury, którą reprezentuje. W efekcie gwałty są traktowane jako narzędzie czystki etnicznej ${ }^{54}$.

w kontekście wojny domowej w Rwandzie identyfikuje uprzedmiotowienie i instrumentalizację reprezentacji kobiety Tutsi. Badacz opisuje przedwojenny status kobiet Tutsi jako będących trudno dostępnym przedmiotem pożądania mężczyzn Hutu, a jednocześnie ulokowanych w neurotycznej konfiguracji pragnienia, niepokoju i podejrzeń. Poślubienie kobiety Hutu przez mężczyznę Tutsi było wskaźnikiem uprzywilejowanej pozycji społecznej. W kwietniu 1994 r. „wszystko stało się dozwolone. Radio nawoływało mężczyzn: zasmakujcie tego, czego one tak długo wam odmawiały, bierzcie je, są wasze" (W. Tochman: Dzisiaj narysujemy śmierćc.., s. 43).

${ }^{52}$ Zob. J. Gottschall: Explaining Wartime Rape..., s. 129.

${ }^{53}$ Por. R. van Boeschoten: The Trauma of War Rape: A Comparative View on a Bosnian Conflict and a Greek Civil War. "History and Anthropology" 2003, Vol. 14, no 1, s. 42.

${ }^{54}$ Zob. C.S. Snyder, W.J. Gabbard, J.D. May, N. Zulcic: On the Battleground of Women's Bodies: Mass Rape in Bosnia-Herzegovina. "Affilia" 2006, Vol. 21, Issue 2, s. 186-190. 
Inger Skjelsbæk stawia tezę, że studiowanie specyfiki gwałtów wojennych i ich konsekwencji wymaga uwzględnienia intersekcjonalności czterech elementów, którymi są: funkcjonowanie w roli ofiary, funcjonowanie w roli ocalonego, tożsamość etniczna i tożsamość genderowa. Wnioskiem z przeprowadzonych przez Skjelsbæk badań było stwierdzenie, że można wyróżnić dwa podstawowe typy interpretacji własnej tożsamości w czasie następującym po doświadczeniu gwałtów wojennych - typ etnicznej ocalonej (ethnic survivor) oraz genderowej ofiary (gendered victim). W pierwszym przypadku gwałt jest traktowany jako jedna $\mathrm{z}$ form praktyk towarzyszących konfliktowi etnicznemu, status kobiet i mężczyzn interpretuje się jako równy. W drugim przypadku przemoc opierającą się na praktyce seksualnej rozumie się jako środek do dezorganizacji kultury patriarchalnej, a zgwałcona kobieta jest narażona na stygmatyzację $e^{55}$.

\section{Kontekst postludobójczy}

Funkcjonowanie w kontekście postludobójczym kreuje potrzebę zredefiniowania tożsamości sprawców, obserwatorów i ofiar. Określa potrzebę wypracowania oficjalnej narracji dotyczącej zdarzeń oraz wskazania odpowiedzialnych za nie. Są to procesy bazujące na nazywaniu zdarzeń, procesów i tożsamości poprzez wykorzystanie określonych kodów. W takim ujęciu pomocne może być nawiązanie do teorii Judith Butler, która dokonując opisu performatywnego potencjału języka, wskazuje, że nazwanie jest jednym z komponentów ustanowienia podmiotu $^{56}$. Nazywanie podmiotu podlegającego opresji odbywa się zarówno w fazie poprzedzającej ludobójstwo, jak i w fazie jego realizacji. Jest jednym z elementów praktyk dehumanizacyjnych, finalnie zaś pojawiają się dwa skrajne jego efekty: tabuizacja terminu w sposób właściwy określającego tożsamość ofiar praktyk ludobójczych oraz nadanie symbolom wyrażającym tożsamość znaczenia oporującego. W przypadku tabuizacji komponent tożsamościowy, który w sytuacji genocydalnej stanowił stygmat i narażał na doznanie przemocy, jest traktowany jako cecha dyskredytująca, którą posiadający ją stara się ukryćc ${ }^{57}$. Przykładem takiej tabuizacji jest opisywany przez Macieja Zarembę-Bielawskiego kontekst uzyskania przez nastoletniego chłopca wiedzy, że jego matka jest Żydówką,

${ }^{55}$ Por. I. Skjelsbæk: Victim and Survivor: Narrated Social Identities of Women Who Experienced Rape During the War in Bosnia-Herzegovina. "Feminism and Psychology" 2006, Vol. 16, Issue 4, s. 377-380.

${ }^{56}$ Zob. J. Butler: Walczace słowa. Mowa nienawiści i polityka performatywu. Przeł. A. Ostolski. Warszawa 2020, s. 9.

${ }^{57}$ Por. E. Goffman: Piętno. Rozważania o zranionej tożsamości. Przeł. A. Dzierżyńska, J. Tokarska-Bakir. Gdańsk 2007. 
a on w połowie swojej społecznej tożsamości Żydem. Biografia adolescenta buntującego się przeciw rzeczywistości politycznej, społecznej i kulturowej Polski lat 60. zostaje przerwana w 1969 roku deklaracją matki: „Wyjeżdżamy, jestem Żydówką"58. Wcześniej, będąc siedmioletnim chłopcem, bohater-narrator powieści autobiograficznej pyta matkę: „Jak wyglądają Żydzi” "59? Pierwsza odpowiedź to: „tak, jak ja” ${ }^{\circ}$, ale zaraz po niej kobieta, która podczas drugiej wojny światowej wielokrotnie zmieniała imię: Lili-Liliana-Elżbieta-Iza-Elizabeth, rezygnuje z ujawnienia swojej tożsamości i mówi: „Jak każdy, głuptasie. Nie widzisz, że czytam?"' ${ }^{\text {. }}$ Po dziesięciu latach wraz z informacją o exodusie nazwana zostaje nowa tożsamość bohatera oraz nadany mu komponent roli, którym jest wprowadzenie rodzeństwa w nową tożsamość:

Mama składa los w moje ręce [...] Mama nie mówi młodszym braciom, że jest Żydówką i że musimy uciekać. Prosi, żebym to ja za nią zrobił [...] Mama ufa mi, kocha mnie, muszę ją chronić. Nie będzie musiała tłumaczyć sobie ich min [...] Już wiem, jak to się nazywa [...] un rite de passage ${ }^{62}$.

W antropologii rytuał przejścia jest traktowany jako społecznie i kulturowo uznany akt zatwierdzający zmianę statusu. Jest on realizowany poprzez akceptowane w danym społeczeństwie ceremonie ${ }^{63}$. Zredefiniowanie własnej tożsamości oraz przyjęcie roli pośrednika między „składającą własny los w ręce syna” matką a rodzeństwem wyznaczają moment gwałtownego przejścia bohatera $\mathrm{z}$ etapu młodzieńczości do dorosłości. Zaremba-Bielawski określa je jako komponenty rytuału przejścia. Specyfika sytuacji wyraża się jednak w dwóch elementach: w jej odszczepieniu od matryc kulturowych, w których brak jest opisanego scenariusza, oraz w realizacji przejścia $\mathrm{w}$ warunkach alienacji społecznej, deficytu wsparcia i nadwyżki niepewności. Zatem $\mathrm{z}$ antropologicznego punktu widzenia doświadczenie opisane przez Zarembę-Bielawskiego ma raczej cechy traumy zachodzącej w warunkach niepewności, przymusowej zmiany tożsamości i statusu niż realizowanego w ramach akceptowanej matrycy społecznej, we wspólnocie społeczno-kulturowej, poprzez uznaną ceremonię kontrolowanego rytuału przejścia. Przejściu w przytoczonym przykładzie towarzyszy wyciszanie historii rodziny, brakuje też narracji tożsamościowej, ponadto jest ono realizowane w warunkach odseparowania od dotychczasowej grupy odniesienia i włączenia do nowej, nieznanej struktury. Finalnie bohater powieści (a także jej narrator)

\footnotetext{
58 M. Zaremba-Bielawski: Dom $z$ dwiema wieżami..., s. 102.

59 Tamże, s. 98.

60 Tamże.

61 Tamże.

62 Tamże, s. 102-104.

63 Por. A. van Gennep: Obrzędy przejścia. Systematyczne studium ceremonii. O bramie i progu [...] i o wielu innych rzeczach. Przeł. B. Biały. Wstęp J. Tokarska-Bakir. Warszawa 2006, s. 29-31.
} 
poprzez żmudne docieranie do fragmentów własnej historii rodzinnej i rekonstruowanie jej uzyskuje zdolność precyzyjnego nazywania własnej, sfragmentaryzowanej tożsamości, jej afirmacji oraz rozumienia jej przez pryzmat historii trzech pokoleń rodziny, uwzględniając zarówno krewnych paternalnych, jak i maternalnych.

Kontekst postgenocydalny związany jest z przeżywaniem wstydu, tabuizowaniem tożsamości, zaprzeczaniem odpowiedzialności i winie oraz ze zdefiniowaniem statusu ofiar i sprawców. W fazie tej mogą występować luki w pamięci społecznej, zapominanie, wypieranie faktów ze świadomości. Krzysztof Bierwiaczonek i Tomasz Nawrocki przytaczają za Aleidą Assmann pięć strategii, poprzez które może się wyrażać zacieranie traumatycznej pamięci - są to: kompensacja (tworzenie narracji zrównującej winy własnej grupy z winą innych), eksternalizacja (przypisanie winy innym), wyłączenie (zaprzeczenie wiarygodności wersji wiedzy zawierającej stwierdzenie o winie), milczenie zarówno ofiar, jak i sprawców na temat przeszłości oraz przeinaczanie jej (na przykład poprzez przypisywanie sprawcom roli ofiary ${ }^{64}$. Kontekstowi postgenocydalnemu towarzyszy zaprzeczenie oraz wyciszanie narracji, które mogłyby podtrzymywać pamięć o sprawcach i ofiarach. Na kwestię tę zwraca uwagę między innymi H. Karčić w opisie powojennego Višegradu, będącego miastem na tyle małym, że „wszyscy się w nim znają" 65 , jednocześnie jednak sprawcy ludobójstwa zaprzeczają posiadaniu wiedzy o losach swoich bośniackich sąsiadów oraz o lokalizacji masowych grobów, w których znajdują się zwłoki zamordowanych ${ }^{66}$. Wojciech Tochman w reportażu dotyczącym powojennej Bośni sygnalizuje strategie unikania przez serbskich mężczyzn interakcji z obcymi, przedstawicielami mediów oraz bośniackimi kobietami, które, ,jak mało kto, pamiętają ich twarze, smród i siłę"67. Postgenocydalna przestrzeń publiczna jest nacechowana ambiwalencją wyparcia, zaprzeczenia i winy. Tochman opisuje powojenne Sarajewo jako przestrzeń, w której trudno jest być, ,jak gdyby nigdy nic. Usiąść w kawiarni pomiędzy rodzinami ofiar. Pomiędzy tymi, których się wciąż nienawidzi. Od których się uciekło [...] Uzgodnić, jak było. Wydać zbrodniarzy"68.

W fazie tej pojawia się możliwość zrealizowania rytuałów, które w rzeczywistości genocydalnej były uniemożliwiane - jednym z nich jest pochówek zwłok osób zamordowanych podczas trwającego konfliktu. W reportażu Tochmana przestrzenią identyfikacji szczątków są sala teatralna w wiejskim domu kultury, gdzie odzież i kości rozłożono na terakocie, oraz betonowy barak, gdzie szczątki pomordowanych ułożono na stołach. Identyfikacja szczątków ma dla bliskich

${ }^{64}$ Por. K. Bierwiaczonek, T. Nawrocki: Pomiędzy trauma wojny a codziennością. Pamięć zbiorowa mieszkańców górnośląskiej wsi Bojszowy. Warszawa 2020, s. 21.

${ }^{65}$ M. Zaremba-Bielawski: Dom $z$ dwiema wieżami..., s. 102.

${ }^{66}$ Zob. H. Karčić: Uncovering the Truth..., s. 118.

${ }^{67}$ W. Tochman: Jakbyś kamień jadła..., s. 45.

68 Tamże, s. 41. 
wieloaspektowe znaczenie - emocjonalne (konfrontacja ze śmiercią członka rodziny), poznawcze (uznanie stanu rzeczy), kulturowe (możliwość zrealizowania rytuału pochówku), umożliwia zakończenie „życia w dwóch światach [...] jedną nogą w tamtym, drugą w tym”, oraz egzystencjalne: „Nie ma kości, nie ma pochówku, nie ma jak żyć"70.

Złożone konsekwencje genocydu nie są odnoszone tylko do lat następujących bezpośrednio po zakończeniu konfliktu, ale można analizować je w perspektywie intergeneracyjnej. Przedmiotem eksploracji jest wtedy treść pamięci o ludobójstwie, strategie jej konstruowania, negocjowania. Z kwestią tą związana jest także nie-pamięć, treści wyciszane zarówno przez sprawców, jak i przez ofiary. Problematykę pamięci międzypokoleniowej podejmuje $\mathrm{w}$ autobiograficznym eseju Miljenko Jergović. Pisarz lokuje swoją narrację podczas dwóch wojen, których jednym z komponentów były praktyki ludobójcze. Są to druga wojna światowa oraz wojna domowa w Jugosławii. Jergović - wnuk Babki Štefaniji, „żarliwej Chorwatki" "11, która w jego opinii była zachwycona, że znalazła się „w czarodziejskim świecie Kopciuszka, gdzie dynia staje się karetą, a myszy siwymi końmi”"72, kiedy w 1941 roku pod protektoratem Niemiec i Włoch zostało ustanowione Niezależne Państwo Chorwackie, na którego czele stanął faszystowski polityk i przywódca organizacji nacjonalistycznej Ante Pavelić - wskazuje na kwestie dotyczące rekonstrukcji własnych tożsamości przez reprezentantów kolejnych pokolen' ${ }^{73}$. Odtwarzając przestrzeń społeczną rządów faszystowskich, Jergović stawia pytania dotyczące zachowań swojej babki oraz emocji, jakie odczuwała $\mathrm{w}$ zetknięciu $\mathrm{z}$ otaczającą przemocą:

Jak w tamtych dniach czuła się babka Štefanija, co robiła, z kim rozmawiała, gdzie chodziła? Co powiedziała [...] kiedy miejscowa hołota [...] włamała się do synagogi i rabowała? Czy stała tam i patrzyła? Gdzie była, kiedy w mieście rozbijano witryny serbskich sklepów? Czy rzuciła kamieniem ${ }^{74}$.

Odpowiedzi na te pytania okazują się ważne dla przedstawiciela kolejnego pokolenia, umożliwiają mu zrekonstruowanie swojej tożsamości, uzyskanie wiedzy dotyczącej własnego genealogicznego ulokowania na tle wydarzeń historycznych oraz zrozumienie swoich skryptów wiedzy o świecie, przekonań, emocji, resentymentów.

\footnotetext{
69 Tamże, s. 22.

70 Tamże, s. 29.

71 M. Jergović: Ojciec..., s. 39.

72 Tamże, s. 19.

${ }^{73}$ Por. tamże.

74 Tamże, s. 20.
} 


\section{Podsumowanie}

W przedstawionej analizie jako wiodący paradygmat przyjęłam ujęcie antropologiczne. Specyficzne dla niego pojęcia, takie jak: tabu, rytuał społeczno-kulturowy, rytuał przejścia, performans, pozwalają opisać komponenty praktyk ludobójczych jako bazujące nie tylko na technikach unicestwienia, ale także upokarzania, osłabiania więzi społecznych, destabilizacji wspólnot, tabuizacji tożsamości. Poszukując odpowiedzi na postawione problemy badawcze, dokonałam analizy tekstów z obszarów antropologii i socjologii oraz wybranych opisów rzeczywistości postgenocydalnej przedstawianych w esejach i reportażach. Dobór analizowanych źródeł był celowy: poszukiwałam takich prac, gdzie ulokowane byłyby odniesienia do przestrzeni, w której dokonano zbrodni ludobójstwa, oraz takich, w których treści wyeksponowane zostały wcześniej wymienione komponenty specyficzne dla perspektywy antropologicznej.

W opisach działań ludobójczych zamieszczono charakterystyki krajobrazu, przestrzeni, w której dochodziło do skrajnych form przemocy. Jest to zarówno krajobraz zastany, jak i kreowany przez sprawców w celu ukrycia miejsc dokonanych zbrodni. Obraz przestrzeni stanowi element charakterystyki rzeczywistości postgenocydalnej. Jest to świat zdewastowanych działaniami wojennymi miast i wsi, świat ekshumacji i identyfikacji szczątków zamordowanych osób, a następnie ich godnych pochówków; może on także stanowić teren kontynuacji łamania tabu poprzez rabowanie przedmiotów postrzeganych jako cenne, a znajdujących się pomiędzy szczątkami ludzkimi w masowych grobach. Na poziomie kulturowym przestrzeń postgenocydalna nacechowana jest ambiwalencją wstydu, wyparcia, zaprzeczenia, winy, ale też neutralizacji działań godzących w tabu (na przykład poprzez odwołanie do pragmatyzmu lub dewaluowanie ofiar zbrodni). Przestrzeń ta stanowi również kontekst rekonstrukcji tożsamości, negocjowania i odtwarzania pamięci, zarówno indywidualnej, jak i międzypokoleniowej.

Działania genocydalne nie składają się z aktów przypadkowych, realizowana w ich ramach przemoc bazuje na antropologicznych matrycach łamania tabu kulturowego (na przykład związanego z oddawaniem czci zmarłym oraz tabu seksualnego). Ich celem nie jest jedynie wyrządzenie szkody i cierpienia na poziomie indywidualnym, ale dezorganizacja, osłabienie, a finalnie unicestwienie grupy wyznaczonej jako podmiot działań ludobójczych. Są to także działania służące wyłączeniu członków społeczności poza jej obręb, osłabieniu jej w wymiarze liczebnym, a za pomocą przemocowych praktyk prokreacyjnych - pomnażaniu grupy reprezentowanej przez agresora. Studia nad zarysowaną problematyką są realizowane dzięki wykorzystaniu różnych matryc teoretycznych, na przykład nawiązującej do psychoanalizy, komponentów modelu strukturalnego, teorii stygmatyzacji czy też teorii feministycznej. 


\section{Bibliografia}

Andrić I.: Most na Drinie. Przeł. H. Kalita. Warszawa 1985.

Armoudian M.: In Search of a Genocidal Frame: Preliminary Evidence from the Holocaust and the Rwandan Genocide. "Media, War and Conflict" 2020, Vol. 13, s. 133-152.

Becirević E.: Genocide on the Drina River. New Haven-London 2014.

Bierwiaczonek K., Nawrocki T.: Pomiędzy trauma wojny a codziennością. Pamięć zbiorowa mieszkańców górnośląskiej wsi Bojszowy. Warszawa 2020.

Blackwell D.: Counselling and Psychotherapy with Refugees. London 2005.

Boeschoten R. van: The Trauma of War Rape: A Comparative View on a Bosnian Conflict and a Greek Civil War. "History and Anthropology" 2003, Vol. 14, no 1, s. 41-54.

Braidotti R.: Po człowieku. Przeł. J. Bednarek, A. Kowalczyk. Warszawa 2014.

Butler J.: Walczące słowa. Mowa nienawiści i polityka performatywu. Przeł. A. Ostolski. Warszawa 2020.

Canin M.: Przez ruiny i zgliszcza. Podróż po stu zgładzonych gminach żydowskich w Polsce. Przeł. M. Adamczyk-Garbowska. Warszawa 2019.

Comission on Human Rights, Forty-ninth Session, Agenda Item 27, Report on the Situation of Human Rights in the Territory of the Former Yugoslavia Submitted by Mr. Tadeusz Mazowiecki. Dostępne w Internecie: https://documents-dds-ny.un.org/doc/UNDOC/ GEN/G93/106/07/pdf/G9310607.pdf?OpenElement [data dostępu: 16.07.2020].

Djurdjevic M.G.: Wartime Rapes of Men Remains Taboo in Bosnia. „Balkan Transitional Justice”, 18.05.2017. Dostępne w Internecie: https://balkaninsight.com/2017/05/18/ male-victims-of-war-related-sexual-abuse-shunned-in-bosnia-05-18-2017-1/ [data dostępu: 20.06.2020].

Doubt K.: Understanding Evil: Lessons from Bosnia. New York 2006.

Douglas M.: Czystość i zmaza. Przeł. M. Bucholc. Warszawa 2013.

Freud Z.: Totem i tabu. Przeł. M. Poręba, R. Reszke. Warszawa 1997.

Gennep A. van: Obrzędy przejścia. Systematyczne studium ceremonii. O bramie i progu [...] i o wielu innych rzeczach. Przeł. B. Biały. Wstęp J. Tokarska-Bakir. Warszawa 2006.

Goffman E.: Piętno. Rozważania o zranionej tożsamości. Przeł. A. Dzierżyńska, J. Tokarska-Bakir. Gdańsk 2007.

Gottschall J.: Explaining Wartime Rape. “The Journal of Sex Research" 2004, Vol. 41, no 2, s. 129-136.

Jergović M.: Ojciec. Przeł. M. Petryńska. Wołowiec 2012.

Karčić H.: Uncovering the Truth: the Lake Perućac Exhumations in Eastern Bosnia. “Journal of Muslim Minority Affairs" 2017, Vol. 37, no 1, s. 114-128.

Kępiński A.: Rytm życia. Kraków 1978.

Leder A.: Prześniona rewolucja. Ćwiczenia z logiki historycznej. Warszawa 2014.

Mullins Ch.W.: "We Are Going to Rape You and Taste Tutsi Women". Rape During the 1994 Rwanda Genocide. "British Journal of Criminology" 2009, Vol. 49, s. 719-735.

Nijakowski L.M.: O wyjaśnianiu ludobójstwa i czystek etnicznych za pomoca mitów i emocji. „Kultura i Społeczeństwo” 2006, nr 1-2, s. 153-177.

Nijakowski L.M.: Rozkosz zemsty. Warszawa 2013. 
Nowicka E.: Świat człowieka - świat kultury. Warszawa 1991.

Olsen W.C., Csordas Th.J.: Introduction. In: Engaging Evil: A Moral Anthropology. Eds.

W.C. Olsen, Th.J. Csordas. New York-Oxford 2019, s. 1-31.

Pollack M.: Skażone krajobrazy. Przeł. K. Niedenthal. Wołowiec 2014.

Reszka P.P.: Płuczki. Poszukiwacze żydowskiego złota. Warszawa 2019.

Ricoeur P.: Symbolika zła. Przeł. S. Cichowicz, M. Ochab. Warszawa 2015.

Skjelsbæk I.: Victim and Survivor: Narrated Social Identities of Women Who Experienced Rape During the War in Bosnia-Herzegovina. "Feminism and Psychology" 2006, Vol. 16, Issue 4, s. 373-403.

Snyder C.S., Gabbard W.J., May J.D., Zulcic N.: On the Battleground of Women's Bodies: Mass Rape in Bosnia-Herzegovina. "Affilia” 2006, Vol. 21, Issue 2, s. 184-195.

Takševa T.: Genocidal Rape, Enforced Impregnation, and the Discourse of Serbian National Identity. "Comparative Literature and Culture" 2015, Vol. 17, Issue 3, s. $2-8$.

Taylor Ch.: Nowoczesne imaginaria społeczne. Przeł. A. Puchejda, K. Szymaniak. Kraków 2010.

Tochman W.: Dzisiaj narysujemy śmierć. Wołowiec 2010.

Tochman W.: Jakbyś kamień jadła. Sejny 2002.

Tokarska-Bakir J.: Okrzyki pogromowe. Szkice z antropologii historycznej Polski lat 1939-1946. Wołowiec 2012.

Vulliamy E.: Wojna umarła, niech żyje wojna. Bośniackie rozrachunki. Przeł. J. Ochab. Wołowiec 2016.

Wasilewski J.S.: Tabu. Warszawa 2010.

Zaremba-Bielawski M.: Dom z dwiema wieżami. Przeł. M. Kalinowski. Kraków 2018.

Ewa BIELSKa - dr hab., prof. UŚ, zatrudniona w Instytucie Pedagogiki Uniwersytetu Śłąskiego. Jej zainteresowania badawcze koncentrują się na problematyce traumy społeczno-kulturowej, oporu, teorii krytycznej. Jest autorką oraz współautorką czterech monografii zogniskowanych na problematyce oporu społecznego, zagadnieniach identyfikacji oraz transformacji społeczno-kulturowej. 